\title{
Does the Cohesion Policy Decrease Economic Inequalities in the European Union?
}

\author{
Radmila Jovančević* \\ Tomislav Globan* \\ Vedran Recher**
}

\begin{abstract}
This paper examines the impact of the EU Cohesion Policy on the relative development of EU countries as well as on the development of NUTS- 2 regions within member states. The main hypothesis is that the Cohesion Fund payments are reducing inequalities between member states, while failing to decrease the regional inequalities within member states in the European Union. The basic conclusion is that Cohesion funds should not be viewed as the only solution for the problem of regional inequalities in the EU, but rather as a complementary policy instrument to national regional policies. However, the problem of creating institutional capacity for the withdrawal of the Cohesion resources remains emphasized, especially in new member states with lower real GDP growth, in order to compete for projects of highest multiplicative effects on the economy.
\end{abstract}

Keywords: economic and regional inequalities, Cohesion Policy, convergence, European Union, European integration

JEL Classification: D63, O47, R11

\section{Introduction}

The Cohesion Policy is, together with the Common Agricultural Policy, the financially most significant common policy of the European Union. The goal of the Regional and Cohesion Policy has been defined in the Treaty establishing the European Community (Articles 2 and 4), which emphasizes the regional policy as a supporter of economic and social development with higher employment and equitable and sus-

\footnotetext{
* Radmila Jovančević and Tomislav Globan are at University of Zagreb, Faculty of Economics and Business, Zagreb, Croatia.

** Vedran Recher is at Institute of Economics, Zagreb, Croatia.
} 
tainable growth. In the 2014-2020 financial framework the Cohesion Policy resources make up one third of the EU budget (351.8 billion EUR), which makes the Cohesion Policy as the main investment instrument of the EU. Regional and Cohesion Policy funds are responsible for financing strategic transportation and communication infrastructure. They encourage the shift to the environmentally responsible economy, development of small and medium enterprises (SME), innovation and competitiveness, job creation, modernization of educational systems and creation of equitable society.

However, in spite of the wide range of investments and allocation of funds for economic and social development, the EU is still characterized by large economic disparities which were exacerbated by the recent economic crisis. Therefore, it is easy to comprehend the fact that in every new financial perspective the principle goal is to eliminate the limitations apparent in the previous financial plan. In the new 20142020 financial framework economic disparities between core and the periphery have been more accentuated and the necessity to come up with solutions to the problems which arise from development inequalities of these regions has been emphasized (Jovančević, 2012).

The aim of this paper is to analyse the link between the Cohesion Policy and economic inequalities in the European Union. With the widening of the EU, the need to converge the development of its member states has become more apparent. The EU Cohesion Policy became significant as late as in 1986 after the accession of Spain and Portugal, by establishing the Cohesion Fund. The Cohesion Policy is not a simple mechanism of redistribution between countries and regions. Primarily, its purpose is to direct financial transfers towards achieving two goals: regional development and economic convergence. Responsibility for regional policy in member states is divided. In accordance, regional policy measures depend on the decisions of the central government as well as those of regional authorities. The European Commission strategy emphasizes the importance of the involvement of regional authorities in the decision making process (implementing and financing measures).

Today, the Cohesion Policy is the second largest budgetary expense of the EU and it is therefore crucial to explore the justification of invested funds in the context of achieving the established goals, which is the main aim of this paper. The core hypothesis is that the Cohesion Fund payments decrease the cross-country inequalities, but on the other hand increase regional inequalities within individual countries. Apart from justifying the invested funds, it is important to establish if the Cohesion Policy reforms had done enough to enable the objective possibility of achieving the policy goals. Although literature that studies various effects of the Cohesion Policy on the member states' economies is not scarce, it is difficult to conclude that the connection has been unambiguously confirmed. As a consequence, this paper tries to additionally explore this research area by conducting the panel analysis.

The paper is structured as follows. The second section presents the overview of the existing literature dealing with the effectiveness of the Cohesion Policy. The third 
section consists of methodology details, while the fourth carries out data sources and descriptively analyses the regional inequalities in the EU. The fifth section presents and discusses the results of the panel analysis. The final section highlights the main conclusions of the conducted research.

\section{Literature Review}

Estimating the impact of the EU Cohesion Policy on the convergence of member states contains a problem that has often been overlooked. Underdeveloped regions could grow faster due to the lower initial level of development, regardless of the amount of received cohesion funds. The key question that arises is: is the generated growth in underdeveloped regions sufficient to justify the amount of funds spent on the convergence policy? This section provides an overview of the existing analyses of the effectiveness of the Cohesion Policy.

Amin and Tomaney (1995) attribute low growth rates, high unemployment rates and rising regional disparities in Europe to the failure of the neoliberal project since the 1980s. However, they stress the existing tensions inside EU policy-making between market-led solutions and active intervention in order to achieve economic expansion, social justice and solidarity. Furthermore, they point to the fact that innovations in regional policy, in terms of helping underdeveloped regions to improve their growth, employment and to reduce poverty, is in a shadow of market-oriented policies of a significantly larger scope. Sala-i-Martin (1996) compares regional growth and the cause of convergence in the EU and the US and comes to the conclusion that regional policy of the EU is a failure. Boldrin and Canova (2001) come to the similar conclusion by comparing the regional growth in fund receiving regions in the EU with the growth in non-receiving regions.

Jovančević and Globan (2014) analyzed the correlation between received EU funds and GDP per capita convergence and showed that the financial crisis has had an impact on the weaker convergence of NMS with the old EU-15 in the period 2007-2013. Taking into account economic indicators, GDP per capita at PPP and the inflow of FDI in the NMS, the authors showed that the impact of FDI on the convergence of NMS was strong in the whole period of analysis (2000-2012), however it was less pronounced in the second period (2007-2013), after the crisis, which resulted in poor results for economic development. Martin (2005) reveals the evidence of convergence between member states, but not between the regions. He explores the trade-off between growth and regional inequalities stating that gains in productivity cannot be used as an argument for regional policy. Theory and evidence suggest that the regional concentration of economic activity improves efficiency. Thus, the EU must decide - wheter it will (i) try to limit or even reverse the process of spatial concentration or (ii) focus its policies on the acceleration of convergence between the underdeveloped and developed countries. 
Bouvet (2010) investigates income inequalities between 197 European regions in the period 1977-2003. She uses panel analysis with the Gini coefficient as a measure of inequality within individual countries. Independent variables are divided into four groups: (i) demographic, (ii) macroeconomic stability, (iii) institutions and policies and (iv) the impact of the EMU accession. She concludes that the regional inequality has decreased in the observed period due to decreased cross-country inequalities. This result justifies the funds invested in the Cohesion Policy. However, Bouvet (2010) warns that the inequality in the EU is still two times larger than in the US. Furthermore, the analysis is conducted for the pre-crisis period which puts a large question mark on the relevance of these results today.

Becker (2012) suggests that the transfers aiming to increase convergence have, on average, been efficient in generating additional growth in the receiving regions, but also states that the system can be improved. He argues that not all regions are equally good at utilizing allocated funds to induce additional growth. Thus, the allocation of resources to the regions with below-average levels of education of the workforce and low-quality government is a waste of scarce resources. The solution he offers for these regions is that their investments must be focused on education and government quality as means to build the absorption capacity for future EU funding. Obviously there is no consensus in the literature whether regional policy has been succesful or whether its funding has been reasonably justified. The aim of this paper is to further analyse the effects of the Cohesion Policy in an attempt to offer a more convincing answer to this question.

\section{Methodology}

In order to test the hypothesis stated in the introduction, we estimate a panel model and employ Granger causality tests. Variables that enter the analysis are $w c v$ (weighted coefficient of variation of real GDP per capita in 2005 prices), sust (GDP per capita in PPS, EU-28=100), koh (paid funds from the Cohesion fund, normalized by the country's GDP), $b d p$ (real GDP per capita), zapp (employment in the primary sector as a share in total employment), zaps (employment in the secondary sector as a share in total employment), akt (activity of working age females) and soc (social transfers as a share in the GDP of the country). Weighted coefficient of variation is calculated as:

$$
w C v=\frac{1}{\bar{y}}\left[\sum_{i=1}^{n} p_{i}\left(\bar{y}-y_{i}\right)^{2}\right]^{1 / 2}
$$

where $\bar{y}$ is the country's average GDP per capita, $y_{i}$ is the GDP per capita of region $i, p_{i}$ is the share of the country's total population in region $i$, and $n$ is the number of spatial 
units. The advantages of this measure are that it is mean-independent, independent of the sizes and the number of spatial units, and robust against single extreme observations (Lessman, 2013). Moreover, it satisfies the Pigou-Dalton transfer principle which states that a transfer from rich to poor regions should reduce the inequality measure (Todaro and Smith, 2005; Lessman, 2013). WCV is a value between 0 and 1 , where 0 implies perfect equality between regions.

The relationship between the Cohesion Policy funds and inequalities is first estimated by analysing the correlation between variables koh and wcv, and koh and sust for the cross-country inequalities. In the next step, an unbalanced panel is estimated. GDP per capita in PPS in percent of the EU-28 average, denoted as sust, is chosen as the dependent variable. The key independent variable is the share of the paid cohesion funds in the GDP, denoted as koh. The control variables are the usual determinants of inequality from the literature (Milanovic, 1994: Bouvet, 2010; Lopez and Perry, 2008), namely the activity of working age females, real GDP per capita levels, social transfers as a share in the GDP of the country, employment in the primary sector as a share in total employment, and employment in the secondary sector as a share in total employment.

After conducting the Hausman test, which serves to determine wheter to use fixed effects or random effects model, the latter is used. The data is transformed with logaritmic transformation for more intuitive economic interpretation.

The following equation has been estimated:

$$
\begin{gathered}
\left\{\begin{array}{l}
\ln s u s t_{i t} \\
\ln w c v_{i t}
\end{array}\right\}=\alpha+\beta_{1} \ln k o h_{i t}+\beta_{\mathbf{2}} \ln a k t_{i t}+\beta_{3} \ln b d p_{i t}+ \\
+\beta_{\mathbf{4}} \ln s o c_{i t}+\beta_{5} \ln z a p p_{i t}+\beta_{6} \ln z a p s_{i t}+\left(v_{i}+u_{i t}\right)
\end{gathered}
$$

where $v_{i}$ and $u_{i t}$ are mutually uncorrelated error terms.

Afterwards, the Granger causality test is conducted to check if there is causality between the variables of interest, and if so, in what direction.

\section{Empirical Data and Analysis}

The data on paid cohesion funds are acquired from the European Commission; real GDP per capita is calculated based on the Eurostat data, data for employment in primary and secondary sectors is acquired from the World Bank data. Working age female activity, GDP per capita in PPS and social transfers ${ }^{1}$ data are all acquired from Eurostat.

The European Union consists of 28 member states and 273 NUTS-2 regions. Six states consist only of one NUTS-2 region: Estonia, Cyprus, Latvia, Lithuania, Luxembourg and Malta. Therefore, listed countries are excluded from the analysis of 
regional inequalities since it is difficult to disaggregate them to the regional level. Furthermore, Croatia is excluded from the analysis because of its late accession to the EU in 2013 which makes the data on the regional level too scarce to conduct the appropriate analysis.

Figure 1 displays the movement of the weighted coefficient of variation (WCV) of real GDP per capita (in 2005 prices) in EU-28 for the period 2000-2011. The trend of decreasing inequalities is evident for the period until 2008, after which, due to the crisis, inequalities again started to rise. It is important to emphasize here that the decrease from 0.51 in 2000 to 0.45 in 2011 does not imply a strong inequality decrease, considering the relatively large time-span of 12 years. Besides, the WCV level of 0.45 still presents a relatively large level of inequality between countries, and the goal of the Cohesion Policy should be to significantly reduce this number to achieve economic and social cohesion.

Figure 1: Weighted coefficient of variation in the EU-28, 2000-2011

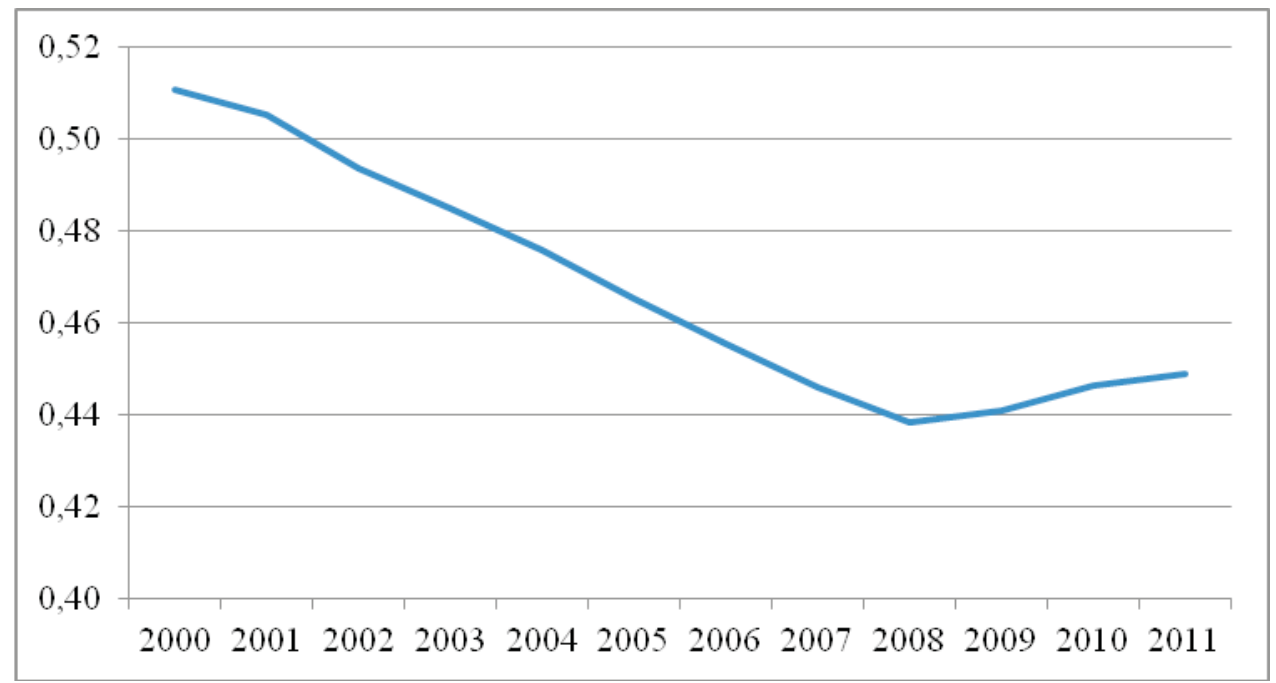

Source: Authors' calculations based on the data from (Eurostat, 2014)

Turning to regional inequalities within member states, a useful illustration to begin with is the comparison of the average real GDP per capita (in percent of the EU-28 average) of the first tertile of developed regions and the bottom tertile of underdeveloped regions. This comparison is crucial to understand the problem of regional inequalities, since the funds are allocated to statistical regions with the GDP per capita lower than $75 \%$ of the EU average. This analysis highlights the following facts: the level of the average real GDP per capita in most developed regions is 59\% larger than the EU average, while in the least developed regions it amounts to $50 \%$ of the EU average. 
If the numbers are disaggregated, the results are even more worrisome. For example, Inner London has 4.5 times larger GDP per capita than the EU average, while the GDP per capita in the least developed NUTS-2 region in the EU (Severozapaden in Bulgaria) amounts to only 11\% of the EU average (Eurostat, 2014). Table 1 and 2 display the most and least developed NUTS-2 regions, measured by purchasing power standards (PPS) per capita. In Table 1, Inner London is leading with $321 \%$ of the EU average in PPS per capita. However, when comparing the relative development in PPS with that in real GDP per capita, some differences are apparent. For example, and perhaps somewhat surprising, Bratislavský kraj lies in the fourth place with PPS per capita at $186 \%$ of the EU average, while Prague lies in the seventh place with PPS per capita at $171 \%$ of the EU average. Both are positioned ahead of Vienna in the tenth place. Furthermore, there is quite a diversity of countries in top 10 NUTS-2 regions. From the 10 most developed regions, three are from Germany, and one from the UK, Belgium, Slovakia, France, the Netherlands, Sweden, Czech Republic and Austria, respectively. This speaks in favour of the hypothesis that the regional inequalities are a larger obstacle to cohesion than cross-country inequalities since the most developed Slovakian region is on par with regions from Germany and France, while at the same time Slovakia is not at the top of the developed countries list. Therefore, these differences obviously cannot be reduced by further developing Bratislava, but rather by developing the Slovakian areas which are below the EU average.

Table 1: Most developed NUTS-2 regions in PPS per capita in 2011

\begin{tabular}{|l|c|c|}
\hline Region & PPS per capita & PPS per capita in \% of EU average \\
\hline Inner London (UK) & 80,400 & 321 \\
\hline Brussels Hoofdstedelijk Gewest (BE) & 55,600 & 222 \\
\hline Hamburg (DE) & 50,700 & 202 \\
\hline Bratislavský kraj (SK) & 46,600 & 186 \\
\hline Île de France (FR) & 45,600 & 182 \\
\hline Groningen (NL) & 45,600 & 182 \\
\hline Stockholm (SE) & 43,300 & 173 \\
\hline Praha (CZ) & 42,900 & 171 \\
\hline Oberbayern (DE) & 42,200 & 168 \\
\hline Wien (AT) & 41,300 & 165 \\
\hline Darmstadt (DE) & 40,500 & 162 \\
\hline
\end{tabular}

Source: Eurostat (2014)

Table 2 displays the 10 least developed NUTS-2 regions in the EU. A significantly more homogenous structure is immediately evident. Nine out of 10 least developed 
regions are from Bulgaria and Romania and only one (most developed in this list) from Poland.

Table 2: Least developed NUTS-2 regions in PPS in 2011

\begin{tabular}{|l|c|c|}
\hline Region & PPS per capita & PPS per capita \% EU average \\
\hline Lubelskie (PL) & 11,100 & 44 \\
\hline Nord-Vest (RO) & 10,500 & 42 \\
\hline Sud-Est (RO) & 9,900 & 39 \\
\hline Severoiztochen (BG) & 9,400 & 38 \\
\hline Yugoiztochen (BG) & 9,500 & 38 \\
\hline Severna i yugoiztochna Bulgaria (BG) & 8,600 & 34 \\
\hline Yuzhen tsentralen (BG) & 8,100 & 32 \\
\hline Severen tsentralen (BG) & 7,800 & 31 \\
\hline Severozapaden (BG) & 7,200 & 29 \\
\hline Nord-Est (RO) & 7,200 & 29 \\
\hline
\end{tabular}

Source: Eurostat (2014)

Although the disparities are smaller when observing the purchasing power parity instead of current prices (for details see Jovančević, 2012), they are still quite large. While underdeveloped regions are at the one third of the EU average, people in most developed regions are twice as rich as the average European.

\section{Results and Discussion}

\section{Cohesion and inequalities between countries}

The previous analysis revealed a downward trend in the level of inequalities between EU countries until 2008, after which the trend reverses and inequalities started to rise (Figure 1). Now we examine the correlation between the WCV from Figure 1 and total paid cohesion funds normalized by the GDP throughout the 2001-2011 period (Figure 2). Our analysis suggests that the Cohesion Policy is successful in decreasing economic disparities. The correlation is relatively strong, and an approximation with the linear trend shows that a rise in the share of paid cohesion funds in the GDP decreases WCV, i.e. inequalities between countries. 
Figure 2: Weighted coefficient of variation for EU-28 vs. the share of paid cohesion funds in GDP in the period 2001-2011

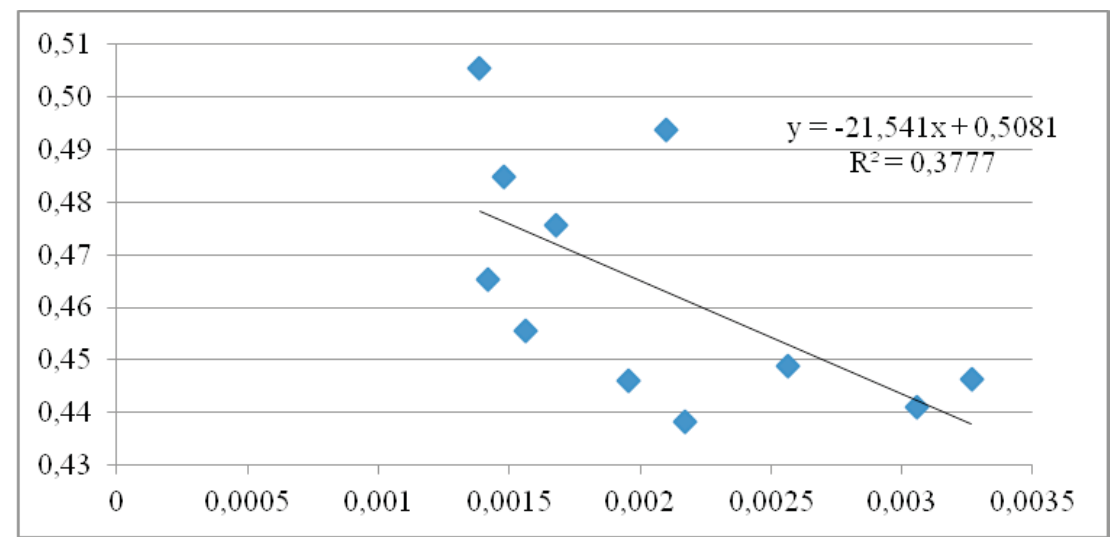

Note: WCV for EU-28 is displayed on the y-axis, while the share of paid cohesion funds in GDP is displayed on the $\mathrm{X}$-axis.

Source: authors' calculations based on the data from (European Commission, 2013; Eurostat, 2014)

However, since only the Cohesion Fund beneficiaries are observed here, it would be useful to analyse the relationship between only those 16 countries. In Figure 3, the weighted coefficient of variation between those 16 member states in the period 2000-2011 is shown. It is obvious that the inequalities between these countries are quite smaller now, which is in accordance with economic intuition. Also, unlike in Figure 1, the positive trend has not been reversed after the crisis, i.e. inequalities are still decreasing but at a lower rate.

Figure 3: Weighted coefficient of variation between 16 countries beneficiaries of the Cohesion Fund in the period 2000- 2011

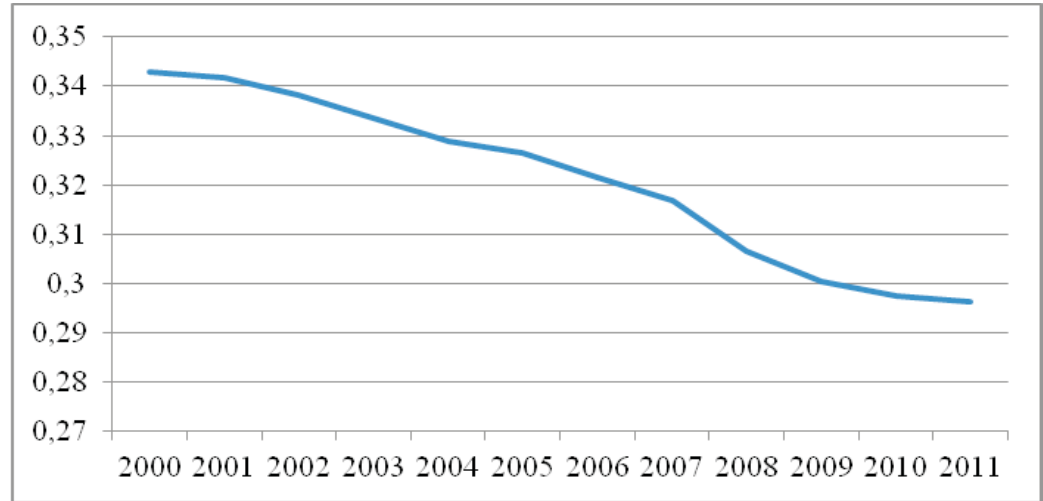

Source: authors' calculations based on the data from (European Commission, 2013; Eurostat, 2014) 
If the same WCV is put into correlation with paid cohesion funds in the 16 member states, as shown in Figure 4, the connection is even stronger than in the previous case. Coefficient of determination is 0.68 which suggests a sound relationship between the two variables. Again, the relationship is in accordance with the goals of the Cohesion Policy.

Figure 4: Weighted coefficient of variation between 16 countries beneficiaries of the Cohesion Fund vs. the share of paid cohesion funds in GDP in the period 2001-2011

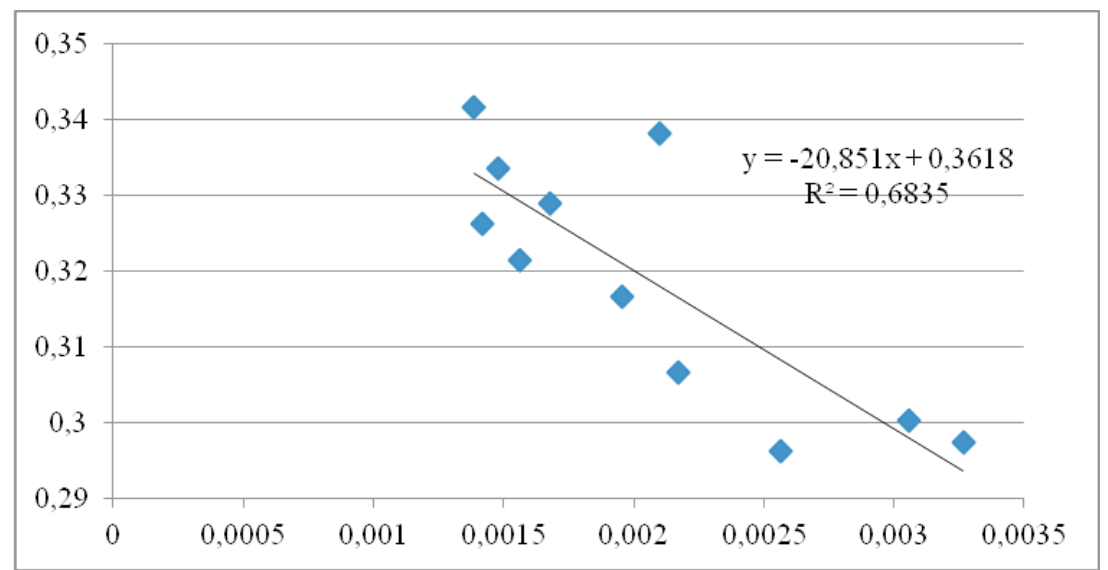

Note: WCV for 16 countries is displayed on the y-axis and total share of paid cohesion funds in total GDP for 16 countries beneficiaries of the Cohesion Fund is displayed on the $\mathrm{x}$-axis.

Source: authors' calculations based on the data from (European Commission, 2013; Eurostat, 2014)

In order to analyse the impact of the Cohesion Policy on economic disparities between countries in more detail, a random effects panel model has been estimated for the 16 countries for the period 2001-2011 (Table 3).

At the conventional levels of significance, all variables are significant in the model, except the variable lnakt (Table 3). In other words, female activity does not affect the inequalities between countries. The signs are all in accordance with economic intuition. If payments from the Cohesion Fund increase by $1 \%$, the convergence to the EU average will, on average increase by $0.012 \%$. Although the relationship is positive, the main question is whether it is strong enough to justify the amount of funds paid? A Granger causality test is later conducted to tackle this question. In the estimated model, real GDP per capita has the biggest positive impact on the inequalities between countries, as expected. Social transfers also have a positive and statistically significant impact. Employment in primary and secondary sectors have a negative impact on convergence with the EU average, as expected. 
Table 3: Estimated panel for the impact of the Cohesion Policy on economic inequalities between EU member states

\begin{tabular}{|c|c|}
\hline Dependent variable & lnsust \\
\hline Number of periods & 11 \\
\hline Number of countries & 16 \\
\hline Total observations & 164 \\
\hline Time period & $2001-2011$ \\
\hline Variable & $\begin{array}{l}\text { Coefficient } \\
\text { (Std. error) }\end{array}$ \\
\hline $\ln k o h$ & $\begin{array}{c}0.012414 * * \\
(0.005354) \\
\end{array}$ \\
\hline $\ln a k t$ & $\begin{array}{c}0.036858 \\
(0.055784) \\
\end{array}$ \\
\hline $\ln b d p$ & $\begin{array}{c}0.543073 * * * \\
(0.021445)\end{array}$ \\
\hline $\ln s o c$ & $\begin{array}{c}0.107473 * * * \\
(0.036655)\end{array}$ \\
\hline $\ln z a p p$ & $\begin{array}{c}-0.050532 * * * \\
(0.007207)\end{array}$ \\
\hline $\ln z a p s$ & $\begin{array}{c}0.209859 * * * \\
(0.043861)\end{array}$ \\
\hline constant & $\begin{array}{c}-1.766161 * * * \\
(0.344300)\end{array}$ \\
\hline $\mathrm{R}^{2}$ & 0.920438 \\
\hline Adjusted $\mathrm{R}^{2}$ & 0.917397 \\
\hline Standard Error of regression & 0.042188 \\
\hline F-statistic & 302.7159 \\
\hline Probability (F-statistic) & 0.000000 \\
\hline
\end{tabular}

Note: $* * *$ denotes significance at $1 \%, * *$ at $5 \%$. Standard errors are in the parentheses.

For further analysis of the invested funds, a Granger causality test between the two variables is conducted ${ }^{2}$, the results of which are shown in Table 4 . The null hypothesis implies that one variable does not Granger cause the other, while the alternative implies causality. As can be seen from Table 4, lagging behind the EU average (lnsust) Granger causes the payments from the Cohesion Fund (the null hypothesis is rejected), which is the expected finding considering that the condition to qualify for the cohesion funds is to be below the EU average in terms of GDP per capita. However, as can be seen from Table 4, reverse causality does not exist. 
Table 4: Granger causality test between the inequalities between EU countries and paid cohesion funds

\begin{tabular}{|l|c|c|c|}
\hline Null hypothesis & Observations & F-statistic & p-value \\
\hline Insust does not Granger cause lnkoh & 130 & 4.61654 & 0.0116 \\
\hline lnkoh does not Granger cause lnsust & & 0.59874 & 0.5511 \\
\hline
\end{tabular}

The model showed a positive correlation between inequalities across member states and paid cohesion funs, but with two important remarks: (i) the relationship is weak and (ii) there is no reverse causality, i.e. paid cohesion funds do not cause the decrease in inequality between countries. It is therefore very hard to demystify and isolate the impact of payments from the Cohesion Fund on the economic inequality between countries. Probably more important than the quantity of the funds per se is the optimal way to use the funds as means to catch up with more developed countries (Jovančević, 2012). The key instrument for achieving this is the institutional framework of a country, as well as the quality of human capital and the level of corruption, which can play an important role in the utilization of funds. The Cohesion Policy surely plays an important role in boosting the development of underdeveloped member states. However, the Cohesion Policy itself is not enough to achieve the convergence between countries. It is interesting that the social transfers in the model above had a greater impact on reducing inequalities than cohesion funds. It is almost paradoxical that, on the one hand, large amounts of money are spent on the "economic and social cohesion" objective. In the same time, there are different measures of fiscal austerity and insistence on reducing the welfare state and budget deficits imposed on countries. It is important to reconcile the objectives of the Cohesion Policy with national economic policies and avoid using conflicting instruments for achieving objectives.

\section{Cohesion and inequalities within a country}

In the previous subsection the analysis was focused on the impact of the Cohesion Policy funds on economic disparities between member states. Here, similar analysis is employed to analyse inequalities between NUTS-2 regions within individual member states, by using $w c v$ as a dependent variable, i.e. the measure of regional inequality. Unlike in the previous subsection, the analysis deals only with 11 countries, because countries with only one NUTS-2 region have been excluded as it is impossible to compute the $w c v$ for them.

Figure 5 indicates the relationship between the average $w c v$ for 11 countries and the share of cohesion funds in GDP for the period 2001-2011. The distinction from Figure 2 and Figure 4 is immediately clear. Here, it is apparent that the rise in Cohesion Fund payments is correlated with the rise in regional inequalities. The most 
"successful" country is Hungary, which has withdrawn most resources (as a share in GDP), and at the same time has the largest $w c v$ of 0.48 .

Figure 5: Average weighted coefficient of variation vs. the share of Cohesion Fund payments in GDP in the period 2001-2011

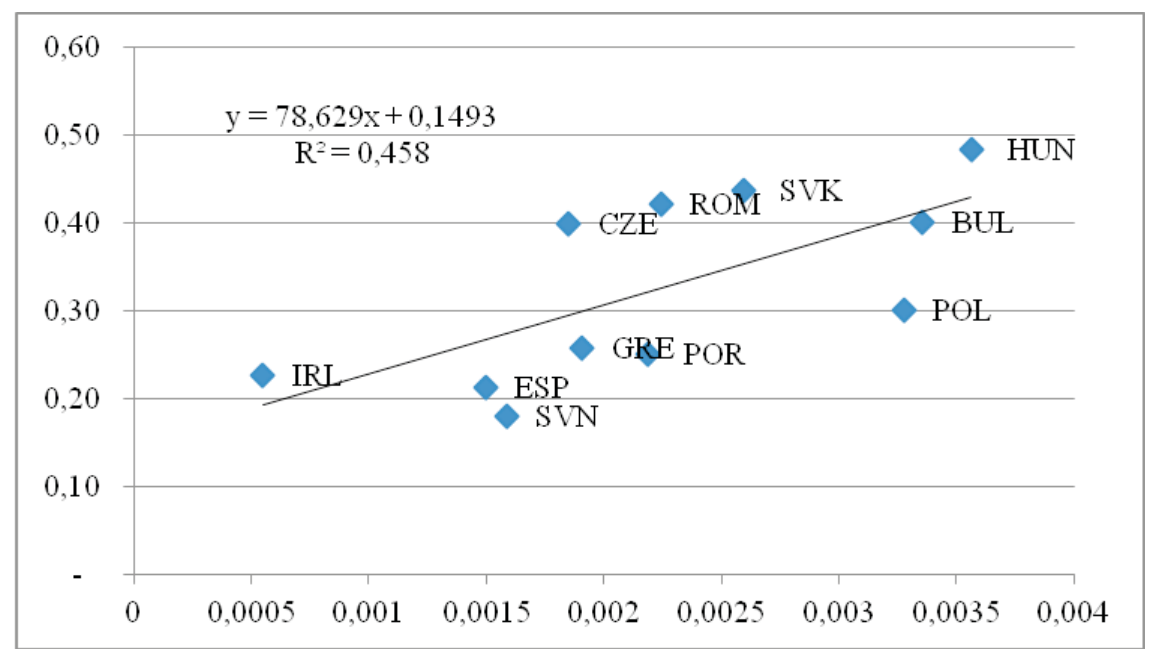

Note: WCV is displayed on the y-axis and the share of paid cohesion funds in GDP is displayed on the $\mathrm{x}$-axis.

Source: authors' calculations based on the data from (European Commission, 2013; Eurostat, 2014)

It is interesting to note that if the period 2001-2011 is divided into two sub-periods, in the first one (2001-2004) there is a negative correlation between the two variables, which suggests that in this period the relationship was in accordance with the Cohesion Policy goals. However, the correlation here is relatively weak, as can be seen from Figure 6. 
Figure 6: Average weighted coefficient of variation vs. the share of Cohesion Fund payments in GDP in the period 2001-2004

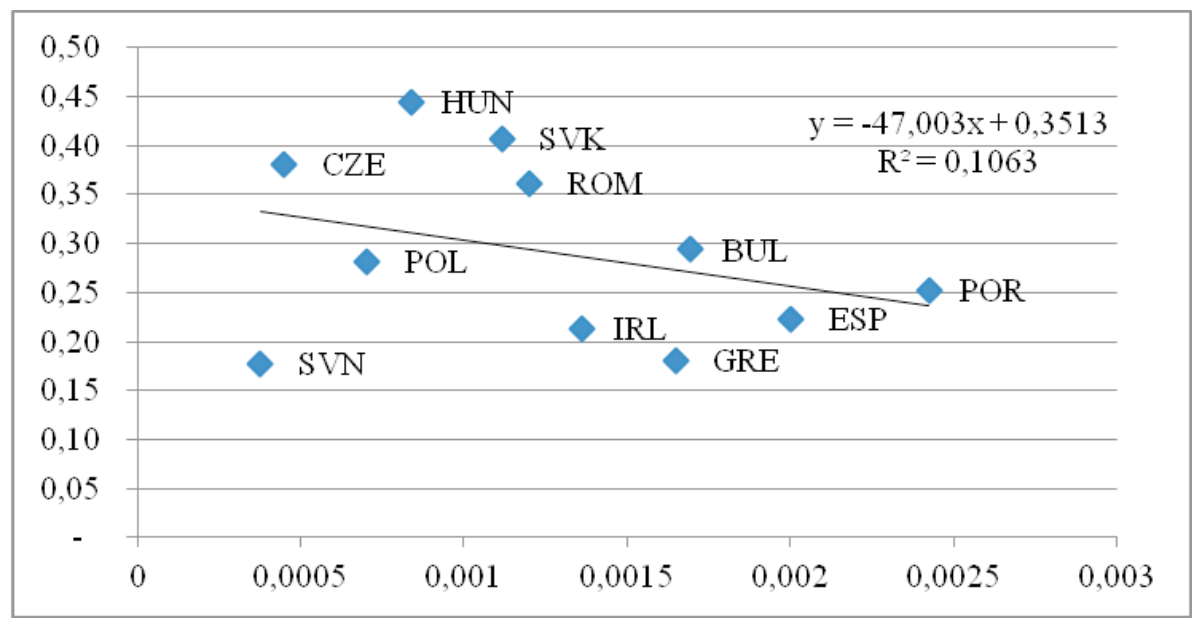

Note: WCV is displayed on the y-axis and the share of paid cohesion funds in GDP is displayed on the $\mathrm{x}$-axis.

Source: authors' calculations based on the data from (European Commission, 2013; Eurostat, 2014)

If the same relationship is observed in the second sub-period, the situation is almost exactly opposite, as shown in Figure 7. Therefore, after the eastern enlargement of the EU, the payments from the Cohesion Fund are positively correlated with the growth of regional disparities. The old member states - Greece, Portugal and Spain are in the lower left part of the chart (i.e. less payments and less inequality) as might be expected, taking into account that they started to withdraw the funds about 15 years earlier. At the same time, the new member states are concentrated in the upper right part of the chart (except Slovenia and Poland). 
Figure 7: Average weighted coefficient of variation vs. the share of Cohesion Fund payments in GDP in the period 2005-2011

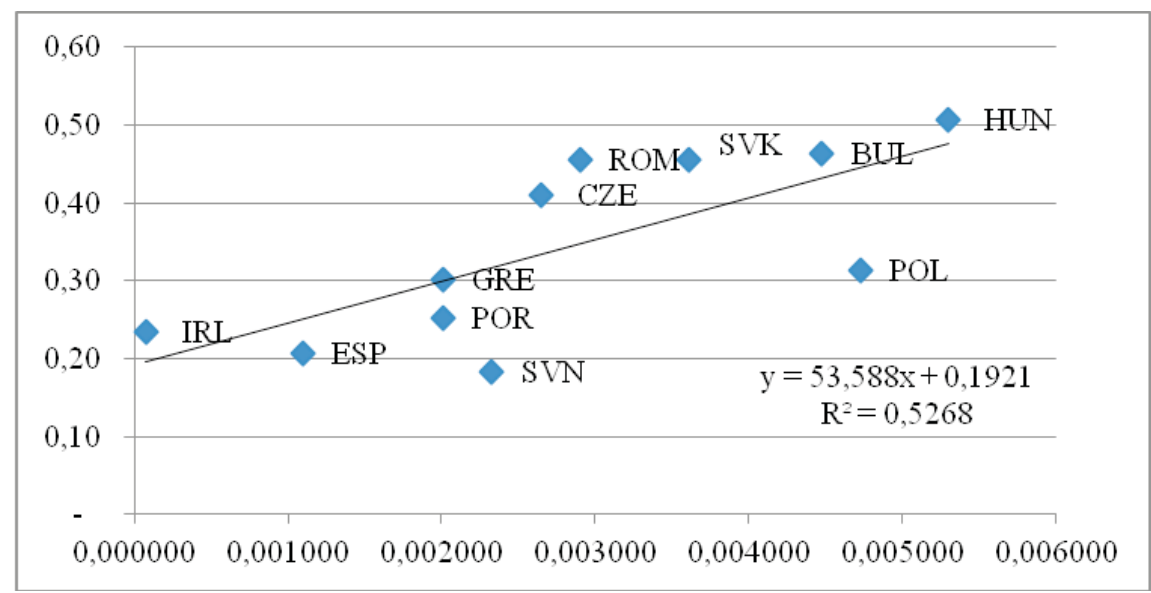

Note: WCV is displayed on the y-axis and the share of paid cohesion funds in GDP is displayed on the x-axis.

Source: authors' calculations based on the data from (European Commission, 2013; Eurostat, 2014)

When the same relationship is observed over time, rather than across countries, the same, if not even stronger conclusions are obtained. Out of 11 countries, only in Ireland and Portugal have the cohesion funds been negatively correlated with the growth in $w c v$. Additionally, this negative correlation is very weak (coefficient of determination below 0.15 ), while positive correlation in all other countries is somewhat stronger. These results have not been included due to space issues but are available upon request.

To confirm these results, a random effects panel model is estimated, results of which are shown in Table 5. At the 5\% level of significance, variables GDP and female activity are not significant in this model. Other variables have signs as predicted. If the share of paid cohesion funds increase by $1 \%$, the weighted coefficient of variation (i.e. regional inequality) will on average rise by $0.05 \%$. Obviously, the impact of all variables is opposite in comparison with the first model, as could be expected. Social transfers could potentially increase regional inequalities because they are expected to be higher in developed regions and larger centres of economic activity than in less developed regions. This represents an additional pull factor for migration and further development of more developed regions. Higher levels of the primary sector employment is a general characteristic of less developed rural areas, so it could be expected that a rise in employment in these regions leads to a decrease in inequality within a country. Likewise, a rise in the secondary sector employment usually entails a rise in the employment in more developed urban areas (since there is less industry in the rural areas) and therefore the inequality within a country should 
rise. The basic conclusion, therefore, is that cohesion payments increase the inequality within a country. However, as said before, this model does not examine the causality between the two, which is why the Granger causality test is conducted.

Table 5: Estimated panel for the impact of Cohesion Policy on economic inequalities within EU member states

\begin{tabular}{|c|c|}
\hline Dependent variable & $\ln w c v$ \\
\hline Number of periods & 11 \\
\hline Number of countries & 11 \\
\hline Total observations & 118 \\
\hline Time period & $2001-2011$ \\
\hline Variables & $\begin{array}{l}\text { Coefficient } \\
\text { (Std. error) }\end{array}$ \\
\hline $\ln k o h$ & $0.048424 *(0.008286)$ \\
\hline $\ln a k t$ & $\begin{array}{r}0.740214 * * * * \\
(0.437647)\end{array}$ \\
\hline $\ln s o c$ & $0.778111 *(0.144239)$ \\
\hline $\ln b d p$ & $-0.023212(0.080855)$ \\
\hline $\ln z a p p$ & $\begin{array}{r}-0.153229 * * \\
(0.071770) \\
\end{array}$ \\
\hline $\ln z a p s$ & $0.681150 *(0.148056)$ \\
\hline constant & $\begin{array}{r}-8.104624^{*} \\
(2.472902) \\
\end{array}$ \\
\hline $\mathrm{R}^{2}$ & 0.920438 \\
\hline Adjusted $\mathrm{R}^{2}$ & 0.917397 \\
\hline Standard error of regression & 0.042188 \\
\hline F-statistic & 302.7159 \\
\hline Probability (F-statistic) & 0.000000 \\
\hline
\end{tabular}

Note: $* * *$ denotes significance at $1 \%, * *$ at $5 \%$. Standard errors are in the parentheses.

Granger causality test results are shown in Table 6. Unlike the first model, there is bidirectional causality here. Regional inequality Granger causes the payments from the Cohesion fund, as expected. But, the payments also Granger cause the rise in regional inequalities, which is a quite remarkable result which should concern the policy makers in the EU. 
Table 6: Granger causality test between inequalities within EU member states and cohesion funds

\begin{tabular}{|l|c|c|c|}
\hline Null hypothesis & Observations & F-statistic & p-value \\
\hline lnwcv does not Granger cause lnkoh & 94 & 4.11537 & 0.0195 \\
\hline lnkoh does not Granger cause lnwcv & & 3.87142 & 0.0244 \\
\hline
\end{tabular}

Based on the evidence provided in the analysis it can be concluded that the EU Cohesion Policy affects the agglomeration of economic activity and enhances the core-periphery disparities within member states.

The conducted analysis certainly opens some crucial questions for the future of the Cohesion Policy as well as for the potential reforms needed to achieve the convergence goals on the state and regional level.

\section{Conclusions}

This paper confirmed the hypothesis that the Cohesion Fund payments decrease the cross-country inequalities, but at the same time failed to decrease regional inequalities within individual countries. Several important findings support this conclusion: (i) inequalities between countries in the EU are negatively correlated with the cohesion payments in the 2000-2011 period, i.e. cohesion payments decreased the disparities between countries; (ii) this correlation is relatively weak; (iii) the causality exists in one direction - the disparities between countries Granger cause the quantity of payments which the country receives; (iv) inequalities between NUTS-2 regions within member states are positively correlated with the cohesion payments, i.e. payments increase the regional inequalities measured by the weighted coefficient of variation, (v) this correlation is relatively strong and (vi) there is bidirectional causality - inequalities Granger cause the quantity of cohesion payments and vice versa. This paper contributes to its field of research by providing new insights into the relationship between Cohesion fund payments and inequalities in the EU both between and within countries - the distinction that has so far mainly been overlooked in the literature. Results imply that the cohesion funds have not been used efficiently in previous financial frameworks, but they should bear more importance in underdeveloped member states in the next financial framework 2014-2020. However, it is important to emphasize some inherent limitations of the analysis. First, when computing the real GDP per capita and WCV, CPI of the member states is used for deflationary purposes. This means that possible differences in prices between regions are ignored. Second, inequalities across countries are analysed only for 16 member states beneficiaries of the Cohesion fund. The inclusion of most developed countries in the analysis would probably have had significant impact on the results. Third, some NUTS-2 regions for 
which the data was not available were excluded from the analysis. These regions are: Brandenburg (DE), Dresden (DE), Chemnitz (DE), Leipzig (DE), Emilia-Romagna (IT) and Marche (IT). Stated conclusions have important implications for EU decision makers. Validity of the allocated funds for the Cohesion Policy is questionable if disparities within member states are growing. Indeed, is it possible to achieve economic and social cohesion if only inequalities between countries are decreasing? Cohesion programs must accentuate investments needed for growth and job creation as means to reduce the unemployment rates, social inequalities and regional disparities. That is why the European Commission is suggesting the concentration of resources in a few important areas such as employment (especially for the youth), education, social inclusion, innovations and energy efficient economy; and is ready to broaden them to ICT infrastructure and measures of digital growth. Examining the effects of these new measures is a potentially fruitful topic for future research. Given that the EU funds are not a particularly strong instrument for the allocation of resources like national budgets, they should not be viewed as the only solution for the problem of regional inequalities in the EU, but rather as a complementary policy instrument to national regional policies. However, the problem of creating institutional capacity to withdraw the Cohesion Fund resources remains emphasized, especially in new member states which were not a part of the program for promotion of competitiveness and employment in previous financial frameworks. The governments in member states with lower real GDP growth have a challenging task to compete for projects of highest multiplicative effects on the economy. This is becoming a more and more important challenge in the context of the recent crisis and the necessity to improve international competitiveness.

\section{NOTES}

${ }^{1}$ Except for Bulgaria in the period 2001-2005, where data is acquired from the IMF.

${ }^{2}$ Granger causality implies precedence, i.e. if one variable Granger causes the other, then the second variable can be described by the movement of the first variable in the previous period.

\section{REFERENCES}

Amin, A., \& Tomaney, J. (1995). Behind the Myth of European Union: Prospects for cohesion. London: Routledge.

Becker, S. O. (2012). EU Structural Funds: Do They Generate More Growth? The CAGE-Chatham House Series No. 3.

Boldrin, M., \& Canova, F. (2001). Inequality and convergence in Europe's regions: reconsidering European regional policies. Economic Policy, Vol. 16 No. 32, 205-253. 
Bouvet, F. (2010). EMU and the dynamics of regional per capita income inequality in Europe. Journal of Economic Inequality, Vol. 8, No. 3, 323-344.

European Commission (2013). Expenditure Breakdown by MS, SF and objective and also SF by year, SF by year and country and SF by year and objective (2000-2013); received by e-mail upon request.

Eurostat (2014). Available at: http://epp.eurostat.ec.europa.eu/portal/page/portal/statistics/search_database.

Jovančević, R. (2012). Izazovi kohezijske politike Europske unije, 2014-2020. In: G. Družić, I. Družić (eds.), Razvojna strategija malog nacionalnog gospodarstva u globaliziranom svijetu, pp. 179-207. Zagreb: Hrvatska akademija znanosti i umjetnosti, Ekonomski fakultet Sveučilišta u Zagrebu.

Jovančević, R., \& Globan, T. (2014). The impact of the EU Cohesion Policy on the regional convergence process of the new member states in the European Union. In: G. A. Papadopoulos, P. H. Ketikidis, \& S. A. Kofteros (eds.), The 7th International Conference for Entrepreneurship, Innovation and Regional Development ICEIRD 2014 Proceedings, pp. 384-393. Nicosia: ICEIRD.

Lessman, C. (2013). Regional Inequality and Internal Conflict. CESIFO WORKING PAPER No. 4112.

Lopez, J. H., \& Perry, G. (2008). Inequality in Latin America: Determinants and Consequences. Policy Research Working Paper No. 4504.

Martin, P. (2005). The geography of inequalities in Europe. SWEDISH ECONOMIC POLICY REVIEW No. 13, 83-108.

Milanovic, B. (1994). Determinants of Cross-Country Income Inequality: An 'Augmented" Kuznets' Hypothesis. Policy Research Working Paper No. 1246.

Sala-i-Martin, X. (1996). Regional Cohesion: Evidence and Theories of Regional Growth and Convergence. European Economic Review, Vol. 40, No. 6, 1325-1352.

Todaro, M. P., \& Smith, S. C. (2005). Economic Development. Prentice Hall. 
